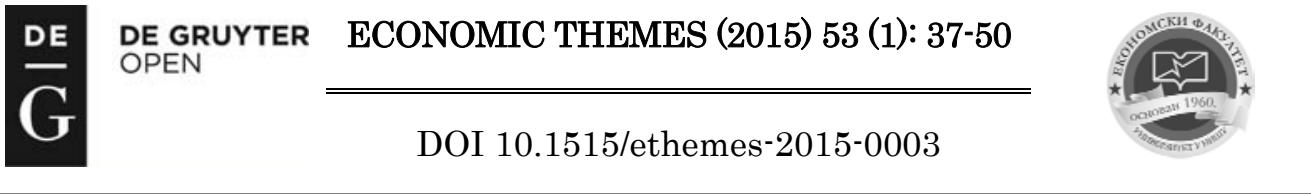

\title{
SATISFYING THE PRINCIPLE OF FAIRNESS IN CONSUMPTION TAX
}

\author{
Marina Đorđević \\ University of Niš, Faculty of Economics, Serbia \\ $\triangle$ marina.dj@ptt.rs
}

UDC

336.226.31

Review paper

Received:

03.12.2014

Accepted:

27.03.2015

\begin{abstract}
Consumption taxes have an important place in the tax systems of modern states. They provide a large amount of revenue for the state budget. However, they are generous, but they are very regressive. It is a bad characteristic. The regressivity problem of the tax burden implies that the consumption tax is burdensome for the population with lower income. They pay similar tax rate as people with high income. The aim of this paper is to point to the existence of the problem of regressivity in underdeveloped and developed countries. This paper analyses the possibilities of reducing this problem in order to satisfy the principle of fairness in taxation.
\end{abstract}

Key words: consumption taxes, VAT, regressivity, coefficient distributive, poverty

\section{Introduction}

Consumption taxes (indirect taxes) are one of the most significant categories of revenue in the budgets of modern states. There is is not a tax system without some form of consumption tax. The object of taxation of these taxes is the sale of products and services. Unlike direct taxes, taxes on consumption come about at the stage of spending income, not at the stage of its creation. Category of consumption tax includes VAT, excise and customs duties. They provide a large revenue for budget, i.e. they are very generous. So, it means that they have a stable and secure income. Indirect taxes are favored tax form by government because they collect the stable flow of funds into the budget. On the other hand, there is a high level of convenience in paying these taxes, since the taxpayer pays taxes, but it does not burden them. The tax burden is shifted to the final consumer, who cannot avoid it because it is included in the price of products and services. 
However, their negative feature is regressivity. These taxes rather burden the parts of the population with lower incomes, since there is the same tax rate for all. The application of the same tax rates in indirect taxation leads to the negation of the principle of payment according to economic strength. The application of the differential tax rates for different categories of products (food and luxury goods consumption) decline the regressive effects of the consumption tax.

In their research Caspersen and Metcalf come to the conclusion that Value Added Tax would be at the least proportional over the life cycle and possibly progressive. Furthermore, adjustment such zero-rating would make a VAT more progressive. With regressivity less of a legitimate concern, the political feasibility of a VAT might be enhanced (Caspersen and Metcalf, 1994).

Richard Murphy says that the $20 \%$ of the poorest households in the UK have both, the highest overall tax burden of any quintile and the highest VAT burden. The VAT burden of $12.1 \%$ of their income is more than double that paid by the top quintile, the VAT burden is $5.9 \%$ of income (Murphy, 2011).

This paper will analyze the problem of fairness in consumption taxes caused by the regressive nature of indirect taxes. The first part will show the structure of the modern tax system in order to position the consumption tax. Then, in the second part of the paper, it will be considered the importance of the consumption tax in the tax systems of modern states. The third part relates to the regressivity in consumption taxes and suggests that these taxes rather burden the parts of the population with lower incomes. In this section, the first research of the problem of regressivity about exploring this problem in Serbia will be discussed. The paper will also explain a significant problem of regressivity of our tax system, since revenues of the taxes on consumption are the most important sources of budget's revenues. Finally, the last section of this paper will offer possible solutions to reduce the problem of regressivity and to satisfy the principle of fairness in consumption taxation.

\section{Analysis of the Structure of Public Revenues in Modern States}

In various tax systems, there is a difference in the structure of tax forms that they include. However, if we compare the tax systems in different countries, we will see in all of them the prevalence of several forms of taxation: VAT, personal income tax, corporate income tax, property tax, excise and customs duties. The revenue from direct taxes provides about $70 \%$ of overall revenues, while the revenue from indirect ones provides a minor amount. 
Table 1 Structure of Tax Ssystems in the OECD Area in \%, 1965-2010

\begin{tabular}{|l|c|c|c|c|c|c||}
\hline \multicolumn{1}{|c|}{ Tax forms } & 1965. & 1975. & 1985. & 1995. & 2005. & 2010. \\
\hline Personal income tax & 26 & 30 & 30 & 27 & 25 & 23 \\
\hline Corporate income tax & 9 & 8 & 8 & 8 & 11 & 10 \\
\hline Social contributions & 17 & 21 & 22 & 25 & 25 & 24 \\
\hline Payroll tax & 1 & 1 & 1 & 1 & 1 & 1 \\
\hline Property tax & 8 & 6 & 5 & 6 & 6 & 6 \\
\hline General consumption tax & 14 & 15 & 16 & 18 & 19 & 20 \\
\hline Specific consumption tax & 24 & 18 & 16 & 13 & 11 & 13 \\
\hline Other taxes & 1 & 1 & 2 & 3 & 3 & 3 \\
\hline TOTAL & 100 & 100 & 100 & 100 & 100 & 100 \\
\hline
\end{tabular}

Source: Revenue statistics OECD 2000-2011, available at:

http://www.oecd-ilibrary.org/ taxation/revenue-statistics-2011 rev stats-2011-en-fr

In developing countries, the ratio of direct and indirect taxes is quite different. Given the lack of a developed economy and a low level of economic and monetary stability in these countries, indirect taxes have a much greater significance. Through them states collect a large amount of the budget's funds for public expenditure. Compared to developed economies, these countries through direct taxes and contributions collect about $40 \%$, and from indirect tax revenues about $60 \%$ (OECD, 2012).

Table 2 The Ratio of Direct and Indirect Taxes as \% of the Total Revenues in Serbia, 2007-2013

\begin{tabular}{|l|c|c|c|c|c|c|c||}
\hline REVENUES & 2007. & 2008. & 2009. & 2010. & 2011. & 2012. & 2013. \\
\hline Tax revenues & 88,9 & 93,3 & 92,0 & 93,0 & 91,8 & 92,1 & 91,1 \\
\hline DIRECT TAXES & $\mathbf{1 6 , 1}$ & $\mathbf{1 7 , 6}$ & $\mathbf{1 9 , 5}$ & $\mathbf{1 6 , 7}$ & $\mathbf{1 4 , 2}$ & $\mathbf{1 4 , \mathbf { 1 }}$ & $\mathbf{1 3 , 0}$ \\
Personal income tax & 10,5 & 11,3 & 11,6 & 11,6 & 7,9 & 6,2 & 5,1 \\
Corporate income & 4,6 & 5,3 & 6,3 & 3,3 & 5,3 & 6,8 & 6,3 \\
tax & 1,0 & 1,0 & 1,6 & 1,8 & 1,0 & 1,1 & 1,6 \\
Property taxes & & & & & & & \\
\hline INDIRECT TAXES & $\mathbf{7 2 , 8}$ & $\mathbf{7 5 , 7}$ & $\mathbf{7 2 , 5}$ & $\mathbf{7 6 , 3}$ & $\mathbf{7 7 , 6}$ & $\mathbf{7 8 , 0}$ & $\mathbf{7 8 , 1}$ \\
VAT & 46,5 & 48,7 & 48,5 & 49,6 & 51,0 & 50,5 & 50,6 \\
Excise & 17,0 & 17,4 & 16,7 & 20,0 & 20,6 & 23,3 & 24,3 \\
Customs & 9,3 & 9,6 & 7,3 & 6,7 & 6,0 & 4,2 & 3,5 \\
\hline Non tax revenues & 11,1 & 6,7 & 8,0 & 7,0 & 7,9 & 7,6 & 8,7 \\
\hline TOTAL & 100 & 100 & 100 & 100 & 100 & 100 & 100 \\
\hline
\end{tabular}

Source: Bulletin of public finance of the Republic of Serbia, September 2014, Ministry of Finance, Available at:

http://www.mfin.gov.rs/UserFiles/File/bilten\%20javne\%20finansije/bilten-121-web(1).pdf, (accessed: 22.12.2014.); the author carried out calculations 
The ratio of direct and indirect taxes in Serbia is even more pronounced in favor of indirect taxes. The consumption tax provides $75 \%$ and the direct tax provides $15 \%$ of the total public revenues.

\section{The Importance of the Consumption Tax in the Tax System}

The economic strength of the taxpayer is indirectly affected by sales taxes. The object of taxation is a consumption of goods and services. Sales taxes date from the ancient times when they could be found in the form of sales tax. Since the tax is included in the product price, the final consumer of products and services bears the tax burden and pays it. These taxes exist in all modern tax systems in two forms, namely as: general consumption tax and taxes on specific goods and services (Đurović-Todorović and Đorđević, 2013, p.11).

Consumption taxes have many advantages and they are widely present in a number of countries. At the same time, they are considered to be one of the most abundant type of public revenues. They provide large resources for budget. These types of taxes also satisfy the principle of comforts, which means that, while the final consumer pays this tax, he/she does this "under anesthesia", so he is not aware of the amount of tax that is submitted. Also, these taxes have depersonalized character, because tax is charged without any discrimination to the personal characteristics of the taxpayer. Regarding the consumption taxes, there is not resistance to taxation because the taxpayer doesn't submit burden. On the other hand, consumers cannot avoid it, since it is included in the price. Consumption taxes are simply levying and easily controlled, so the cost of tax collection is low.

Regresivity has been considered as the main disadvantage of the consumption tax. It means that they burden proportionately more people with less income, which result in adverse social effects. While collecting them it cannot be taken into account the tax ability of the tax addresses, because of the depersonalized nature of these taxes. In addition, consumption taxes induce inflationary potential while introducing or changing tax rates.

The fact is that the indirect taxes are progressive taxes in a negative sense, which strongly affects poor people (Auerbach, 2010, p.21). Since the taxpayers pay sales taxes "under the fiscal anesthesia", the regressive effect of these taxes is larger if the tax rates are higher. The regressive effect of the consumption tax is evident, although it is very difficult to quantificate it in practice. Davies and Kalmus's models of the measurement of the regressivity of consumption taxes are well known among tax experts. Davies' model sets out the rank of the coefficient of correlation between the effective tax rate and the group in accordance to the level of available resources. On the other hand, Kalmus'model measures index of the regressivity of the tax in the lowest groups, according to the level of available resources (Garner, 2010, p. 54). 
The following table presents revenues that have been collected from taxes on consumption in OECD countries over the past eight years.

Table 3 Taxes on Goods and Services as a Percentage of Gross Domestic Product in OECD, 2005-2012

\begin{tabular}{|l|l|l|l|l|l|l||}
\hline & 2007. & 2008. & 2009. & 2010. & 2011. & 2012. \\
\hline Australia & 8,0 & 7,5 & 7,6 & 7,4 & 7,2 & - \\
\hline Austria & 11,5 & 11,6 & 11,9 & 11,8 & 11,8 & 11,9 \\
\hline Belgium & 10,8 & 10,7 & 10,8 & 11,0 & 10,9 & 11,3 \\
\hline Canada & 7,7 & 7,4 & 7,5 & 7,5 & 7,4 & 7,5 \\
\hline Chile & 10,0 & 10,8 & 9,6 & 10,0 & 10,5 & 10,6 \\
\hline Czech Republic & 10,7 & 11,0 & 11,2 & 11,3 & 11,7 & 11,9 \\
\hline Denmark & 16,3 & 15,5 & 15,3 & 15,1 & 15,2 & 15,2 \\
\hline Estonia & 13,1 & 11,8 & 14,4 & 13,7 & 13,4 & 13,7 \\
\hline Finland & 12,9 & 12,9 & 13,4 & 13,4 & 14,3 & 14,4 \\
\hline France & 10,9 & 10,7 & 10,6 & 10,7 & 10,9 & 11,0 \\
\hline Germany & 10,5 & 10,6 & 11,1 & 10,6 & 10,8 & 10,7 \\
\hline Greece & 11,9 & 11,6 & 10,9 & 12,3 & 12,7 & 12,6 \\
\hline Hungary & 15,2 & 14,9 & 15,9 & 16,2 & 15,9 & 17,5 \\
\hline Iceland & 16,4 & 13,6 & 12,0 & 12,4 & 12,5 & 12,9 \\
\hline Ireland & 11,2 & 10,8 & 10,0 & 9,9 & 9,6 & 9,9 \\
\hline Israel & 12,8 & 12,7 & 12,4 & 13,0 & 12,9 & 12,4 \\
\hline Italy & 10,9 & 10,6 & 10,6 & 11,1 & 11,2 & 11,3 \\
\hline Japan & 5,1 & 5,1 & 5,1 & 5,2 & 5,3 & 5,2 \\
\hline Korea & 8,3 & 8,4 & 8,2 & 8,5 & 8,1 & 8,4 \\
\hline Luxembourg & 9,8 & 10,4 & 10,8 & 10,0 & 10,0 & 10,6 \\
\hline Mexico & 9,4 & 12,4 & 8,7 & 9,9 & 10,7 & - \\
\hline Netherlands & 12,0 & 11,9 & 11,7 & 12,0 & 11,6 & - \\
\hline New Zealand & 10,9 & 11,3 & 11,4 & 12,3 & 12,5 & 12,8 \\
\hline Norway & 12,2 & 10,9 & 11,7 & 11,8 & 11,3 & 11,1 \\
\hline Poland & 13,0 & 13,0 & 11,7 & 12,5 & 12,7 & - \\
\hline Portugal & 13,2 & 13,0 & 11,6 & 12,4 & 12,9 & 13,1 \\
\hline Slovak Republic & 11,3 & 10,7 & 10,6 & 10,3 & 10,7 & 9,8 \\
\hline Spain & 9,4 & 8,2 & 7,2 & 8,7 & 8,4 & 8,7 \\
\hline Sweden & 12,6 & 12,9 & 13,5 & 13,4 & 12,9 & 12,8 \\
\hline Switzerland & 6,2 & 6,3 & 6,3 & 6,4 & 6,4 & 6,1 \\
\hline Turkey & 11,5 & 11,0 & 11,2 & 12,5 & 12,6 & 12,5 \\
\hline United Kingdom & 10,4 & 10,3 & 9,9 & 10,7 & 11,5 & 11,6 \\
\hline United States & 4,5 & 4,4 & 4,3 & 4,3 & 4,4 & 4,4 \\
\hline OECD-total & 11,0 & 10,8 & 10,7 & 11,0 & 11,0 & - \\
\hline \hline Sarceitp:/1 & & & & \\
\hline
\end{tabular}

Source:http://www.oecd-ilibrary.org/taxation/taxes-on-goods-andservices_20758510-table6 
Based on the data from the table, it can be seen that taxes on consumption in OECD countries occupy an important place in the public revenues. Their share in GDP in these countries is around $11 \%$. In the last year, the largest shares can be noticed in Hungary (17.1\%) and Denmark (15.2\%), and the lowest ones in Japan (5.2\%) and Switzerland (6.1\%).

If we compare this data with the share of indirect taxes in GDP in underdeveloped countries, we will see that a larger amount of public revenue has been collected through these taxes. This amount in some countries is twice higher than the average revenue in developed countries.

\section{Regressivity Problem in the Taxation of Consumption}

The regressivity of the consumption tax has been a subject of research since the mid-seventies of the twentieth century. As a result of these studies, countries have cut their rates primarily on existential products such as food, water and medicines. The aim of the reduction of the tax rate was encouragement of the consumption of goods that individuals with lower incomes can afford (books, newspapers and magazines, museum tickets, theater tickets, tickets for sport events)(Blažić, 2010, p. 3). In 1970s the first empirical research has been conducted and the foundings have confirmed that differentiated rates could alleviate the regressivity of VAT. A study conducted in the EU has shown that the VAT is more or less proportional. In the case when the consumption was taken as a baseline, VAT showed mild progressivity, while in the case of the incoming base, mild progression has been seen in the taxpayers with lower incomes. However, those with higher levels of income tax have experienced slightly regressive VAT.

If we look at the table, we will see that the coefficient of distributivity shows the relationship between the lowest and the highest income levels.

Table 4 Measurement of the Coefficient of Regressivity in Europe

\begin{tabular}{||l|c||}
\hline The end of the seventies of the twentieth century & $\begin{array}{c}\text { The coefficient of } \\
\text { distributive }\end{array}$ \\
\hline Finland & 1,05 \\
\hline United Kingdom & 0,92 \\
\hline The eighties of the twentieth century \\
\hline Denmark & 0,21 \\
\hline Netherlands & 0,79 \\
\hline Sweden & 0,67 \\
\hline United Kingdom & $>0,86$ \\
\hline
\end{tabular}

Source: Blažić H.,2010, Distributivni učinak PDV-a: usporedna analiza, Ekonomski fakultet, Sveučilište u Rijeci, p. 4 
Based on the data in the table, it can be concluded that Finland and the UK are the first countries that have begun to measure the regressivity. As can be seen from the table, Finland recorded mild progression, while in the UK coefficient was slightly below the unit. Results of other studies indicate that in all the countries, the regressive effect of VAT has been seen.

VAT is usually proportional when measured in relation to consumption. This suggests that reduced and zero rates on existential products have insignificant impact on mitigating the regressivity. This can be explained by the fact that individuals with lower income do not consume so many products such as books, newspapers and tickets for cultural and sporting events. The surveys conducted in the UK, Ireland, Belgium, the USA, Japan and other countries have confirmed that the VAT is regressive.

The research of regressivity problem has attracted the attention of many economists in our country. Serbia follows the model of the EU and its analysis is based on research conducted in the European Union.

If we look at the data, we will see that Serbia collects less than $20 \%$ of revenue from direct taxes, and about $75 \%$ of total public revenues from indirect taxes. The percentage of indirect taxes is extremely high, which confirms our thesis that the tax system in Serbia has expressed regressive character (Ministarstvo finansija, 2009).

Figure 1 Structure of Tax Revenues in Serbia, 2007-2010

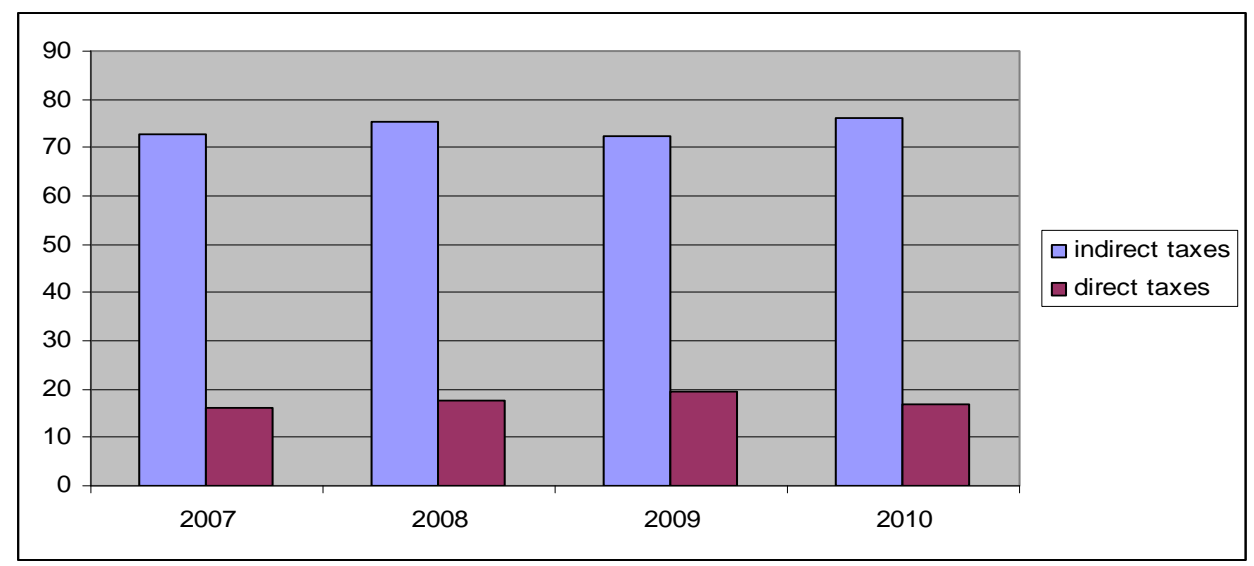

If we analyse Figure 1, It can be seen that the direct taxes do not take a significant place in total tax revenue structure (Đurović-Todorović and Đorđević, 2009). Revenues from indirect taxes are growing from year to year and receive more and more importance. The poor are becoming poorer and the rich are becoming richer. Taxes that directly affect the income and assets of 
individuals are not progressive enough and with the same intensity of load on all layers of the population. In this sense, the gap between rich and poor people is increasingly deepening. The Figure 2 shows that, in the structure of indirect taxes, VAT is prevalent, and excise and customs, which in the far more expensive products and increasing prices. It will, of course, reflect the deterioration of living standards of the population, particularly those categories that are most vulnerable.

Figure 2 Structure of Indirect Taxes in Serbia, 2007-2010

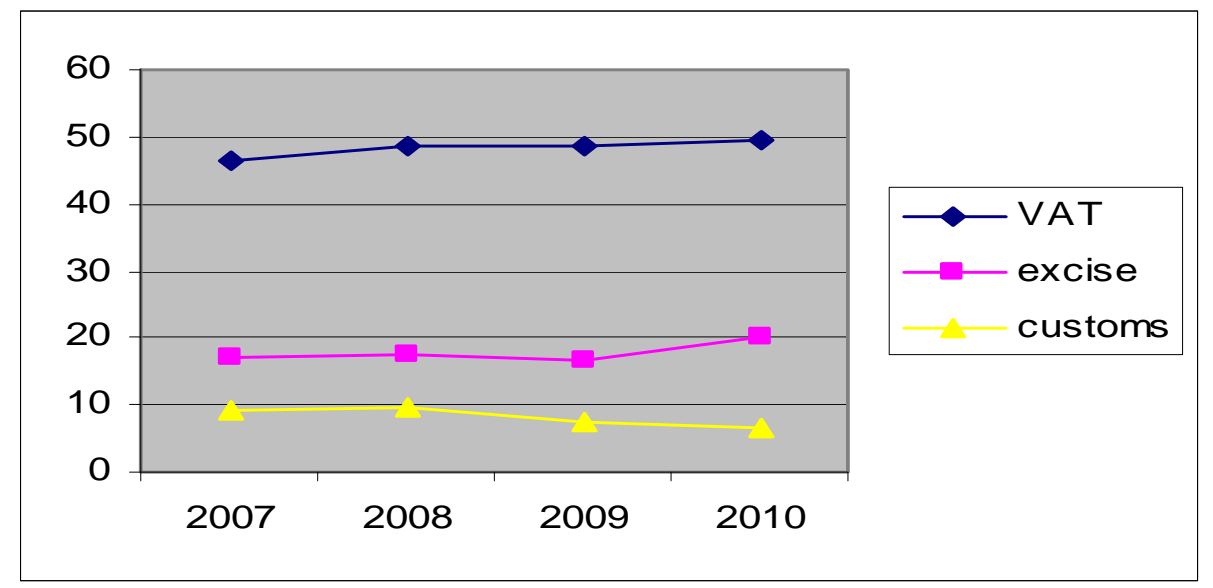

What concerns us is certainly a tendency of our government to continue to increase indirect taxes, rather than execute the reform of direct taxation. This conclusion refers to the fact that the VAT rate has increased by $2 \%$, which has negatively affected the living standards of the depleted population. In this way, the level of regression of the tax system in Serbia will increase.

Research on the regressivity of VAT in Serbia was carried out in 2009 and included a survey on household consumption (a sample of 4,592 households). That was a detailed research so, based on its findings, it can be seen which subjects have the standard rate, reduced rate or exempt from taxation. The research took into account the two constraints: 1) the sale of food in markets places is exempted from VAT and 2) purchase of newly built apartments is not included in household consumption, because it represents the investment cost (Arsić and Altiparmakov, 2012, p. 7).

Data from Table 5 shows mild VAT progressivity. Effective VAT rates range from $10 \%$ to $13 \%$, which is below the standard rate (in that moment standard rate was $18 \%$ ).

Taxes on consumption in Serbia are very plentiful source of public revenue, but they additionally burden the poor users. Every new increase in the rate of 
VAT and excise must be based on a detailed analysis of the economic and social situation in the country. In Serbia, more than a million people live below the poverty line and any new tax increase them further burdens. It is necessary that the tax authorities do not increase the rate of indirect taxes, but to commit to reform of direct taxation and thus provide additional funds for the budget.

Table 5 The Effective Rate of the VAT in Serbia by Level of Income (in\%)

\begin{tabular}{||l|c|}
\hline \multicolumn{1}{|c|}{ Level of income } & The effective rate of VAT \\
\hline Minimum & 10,8 \\
\hline 2 & 11,5 \\
\hline 3 & 11,5 \\
\hline 4 & 11,8 \\
\hline 5 & 11,8 \\
\hline 6 & 12,2 \\
\hline 7 & 12,2 \\
\hline 8 & 12,3 \\
\hline 9 & 12,6 \\
\hline Maximum & 13,0 \\
\hline \hline
\end{tabular}

Source: Arsić M., Altiparmakov N., 2012, Poreska pravičnost PDV sistema u Srbiji, Fiskalni savet Republike Srbije, Beograd, p.11

\section{The Possible Ways of Satisfying Fairness in Taxation of Consumption}

Some possible ways to reduce the regressivity of the tax system are: exempt from VAT, zero rate, the reduced rate and the tax credit.

Exemption from VAT reduces the regressivity of this tax form, primarily because this exemption applies to certain public services such as education and health services. Also, the basic food and medicines may be the object of this release. Some of the products are exempted from VAT because it is difficult to keep record of their consumption. Another group of products, such as food and health services, reduce the regressivity of VAT because it is considered that the increase in income reduces the consumption of these goods. On the other hand, expenditure on education increases as income increases. The liberation of VAT reduces budget revenues, but increases the equity in taxation (Jaime Acosta M., 2011).

It is necessary to estimate well, which products are to be of VAT. Thus, for example, considering food, it should be taken into account that only basic food has to be waived from taxes, not food at restaurants or luxury goods. In this way, fresh fruit and vegetables, meat and milk should be exempted of taxes, as these foods are commonly used. So this will reduce the regressivity of VAT. On the other hand, this job requires high administrative costs. 
Products that are not objects of to taxation are defined by the law on VAT. It often happens that the legislator frees from taxation the products exported by domestic producers in order to increase their competitiveness. The tax exemption is a powerful tool for the economic politics of each country. Also, exemption of basic foods from tax leads to the establishment of social balance. So, it can be concluded that the tax exemption is an important segment of social politics.

Many scholars think that the zero rate of VAT is a better solution than the exemption from taxes. It differs from the examption by the fact that, in the case of export or sale of products, the VAT is going to be refunded. In the EU, several countries still have a zero rate of VAT: Belgium, United Kingdom, Denmark, Ireland, Italy, Malta, Finland and Sweden (European Commission, 2013, pp. 3-6). Until 2013, Croatia has had a zero rate, but then it has abolished this rate. Scandinavian countries have a zero rate. This is possible thanks to the responsible social politics that provides a very high quality of education, health, and safety for the whole population. One of the ways to establish responsible social politics is a zero rate of VAT on products such as bread, milk, books, magazines, tickets for cultural events and medical supplies. Zero rate makes these products cheaper, which is very important for the people with low income, since they usually buy basic foodstuffs. Knowing that a large number of people live below the poverty line, in this way the poverty can be reduced.

The European Union's policy is against the zero rate of VAT. Many countries that had had a zero rate before entering the Union, had to eliminate it and felt the strong price growth, which mostly affected the poorest part of the population. The Scandinavian countries have managed to resist this trend, since their economic politics is focused on the well-being of individuals and families.

The effect of the elimination of zero VAT rate reflected on the price growth and on a fall in consumption of the poorest strata of the population. The reason for this regressive distribution of total welfare loss due to the elimination of the zero VAT rate lies in the fact that the burden of welfare loss of a household is inversely proportional to the percentage by which the products with a zero rate participate into total consumption of households (Švaljek, 2011, p.12).

The reduced rate of VAT is one of the ways to reduce the regressivity of VAT. Many countries choose a reduced rate, since its use provides public revenues and takes care of the most vulnerable part of the population at the same time. The European Union's Directive on the approximation of VAT rates approved the formation of the reduced rate. This Directive allowed the application of one or two reduced rates which may not be lower than $5 \%$. These rates refer to the following products: food, water, medicines, medical supplies, books and other publications, delivery of goods and provision of services for agriculture and other products required by the Directive. Reduced rates may 
also be applied to the delivery of natural gas and electricity, but only if these rates do not threat market competition (Jovanović, 2008, p. 106).

From the perspective of loss of tax revenue, the costs of application of reduced VAT rates are proportional to the multiply prices of goods and services, as well as to the difference between the standard and reduced VAT rate. In order to achieve a specific distribution and social objectives, the creators of the economic politics to mitigate the regressive nature of VAT by applying reduced rates on products and services that are expected to be bought by the people with the lowest incomes.

Table 6 Reduced VAT Rates in the EU in 2013

\begin{tabular}{|l|l|l|}
\hline \multicolumn{1}{|c|}{ State } & Extra reduced rate & \multicolumn{1}{c|}{ Reduced rate } \\
\hline Belgia & - & $6 / 12$ \\
\hline Bulgaria & - & 9 \\
\hline Czech Republic & - & 15 \\
\hline Denmark & - & - \\
\hline Germany & - & 7 \\
\hline Estonia & - & 9 \\
\hline Greece & - & $6,5 / 13$ \\
\hline Span & 4 & 10 \\
\hline France & 2,1 & $5,5 / 7$ \\
\hline Croatia & - & $5 / 10$ \\
\hline Irland & 4,8 & $9 / 13,5$ \\
\hline Italia & 4 & 10 \\
\hline Cyprus & - & $5 / 8$ \\
\hline Letonia & - & 12 \\
\hline Litvania & - & $5 / 9$ \\
\hline Luxembourg & 3 & $6 / 12$ \\
\hline Hungary & - & $5 / 18$ \\
\hline Malta & - & $5 / 7$ \\
\hline Netherlands & - & 6 \\
\hline Austria & - & 10 \\
\hline Poland & - & $5 / 8$ \\
\hline Portugal & - & $6 / 13$ \\
\hline Romania & - & $5 / 9$ \\
\hline Slovenia & - & 9,5 \\
\hline Slovak Republic & - & 10 \\
\hline Finland & - & $10 / 14$ \\
\hline Sweden & - & $6 / 12$ \\
\hline United Kingdom & - & 5 \\
\hline
\end{tabular}

Source: European Commision, 2013, VAT Rates Applied in the Member States of the European Union, Financial Report, Bruxells, str. 3 
Analyzing the data from the table, we can see that some members use rates lower than prescribed, i.e. lower than $5 \%$. These rates are so-called extra or super-reduced VAT rates. Spain, France, Ireland, Italy and Luxembourg use super-reduced rates. These countries apply super-reduce rates to food, medicines, pharmaceutical products, books, magazines and other publications, tickets for cultural and sporting events, public transport, agricultural raw materials etc. (European Commision, 2013, p. 10-14). The application of these rates is justified by social reasons. The goods and services with super-reduced rates are commonly consumed on a daily basis used so any increase of the rates would have a negative effect on the growth of prices and sale of these products.

The tax credit is another way to increase fairness in taxation of consumption. Exempting from VAT or zero rate can be achieved by reducing the regressivity of the tax. However, at the same time will be reduced to its effectiveness and efficiency. The benefits of exemptions and zero rates for wealthier individuals, who have more extensive consumption than the poorest ones, can be useful and they can save more.

One of the alternatives to the VAT's regressive nature is a direct refund of VAT for households with low incomes. This credit should provide an effective redistribution of the burden of VAT from poor to wealthier taxpayers. The biggest refund is provided for those who live below the poverty line. At a time when family income increases to the extent that regressive effects of VAT refunding stops (www.taxpolicycenter.org).

Refunding is known as a tax credit by the Serbian legislation. Our Law on Value Added Tax (www.poreskauprava.gov.rs) defines tax credit in the following way: if the amount of input tax exceeds the amount of tax liability, the taxpayer is entitled to a refunding of the difference. The taxpayer may opt for either refunding the difference or that the difference to be accepted as a tax credit.

\section{Conclusion}

Consumption taxes represent one of the most important categories of tax revenues, due to the fact that they are highly abundant. In underdeveloped economies, they provide more than two-thirds of the revenue intended for the state treasury. In developed countries, the situation is somewhat different, since the direct taxes are abundant, but more than $35 \%$ of total revenues has been collected through the consumption tax.

Regardless of the high abundance of tax on consumption, it is necessary to emphasize the problem of the regressivity of these taxes. They are considered regressive taxes because the same tax rates burden segments of the population 
with different incomes. In this way, the taxpayers, with lower income bear higher tax burden, in proportion to their income.

Based on the previous analysis, it can be concluded that the regressivity problem has been observed in the seventies of the last century and that many countries have carried out the analysis of the degree of the regressivity of consumption tax. Based on these studies, measuring the coefficient of distributivity, it has been concluded that consumption taxes have a negative impact on the economic strength of taxpayers with low incomes. This category of the population bears proportionately greater burden compared to the richer strata of society.

Solution for reducing regressivity and for increasing fairness in taxation of consumption has been found in the introduction of a zero rate of tax on consumption, reduced rates, and in providing tax credits or various types of exemption from payment of these taxes. Each country should adjust the alternative solutions for the problem of regressivity to the character and capabilities of its tax system and to choose those that best suit her.

\section{References}

Arsić M., Altiparmakov N. (2012) Poreska pravičnost PDV sistema u Srbiji. Beograd: Fiskalni savet Republike Srbije.

Auerbach A. J. (2010) A Consumption Tax, The Wall Street Journal

Blažić H. (2010) Distributivni učinak PDV-a: usporedna analiza. Sveučilište u Rijeci: Ekonomski fakultet.

Caspersen E., Metcalf G. (1994) "Is a Value Added Tax Progressive? Annual Versus Lifetime Incidence Measures”, National Tax Journal, 47. The National Bureau of Economic Reacearch; Dostupno na: htpp:/www.nber.org/papers/w4387.pdf

Djurovic-Todorovic J., Djordjevic M. (2009) "Responses of Monetary and Fiscal Policy Makers in Serbia Against The World Economic Crisis". International Conference: Challenges of the World Economic Crisis, Faculty of Economics Nis, Serbia.

Đurović-Todorović, J., Đorđević, M. (2013) Porezi na potrošnju. Niš: Ekonomski fakultet.

European Commision (2013) VAT Rates Applied in the Member States of the European Union. Bruxells: Final report.

Garner C. A. (2010) Consumption Taxes, Macroeconomic Effects and Policy Issue Retrieved

http://www.oecd-ilibrary.org/taxation/taxes-on-goods-and-services_20758510-table6

http://www.poreskauprava.gov.rs/pravna-lica/pdv/zakon/202/zakon-o-porezu-nadodatu-vrednost.html (16.12.2014.)

http://www.taxpolicycenter.org/briefing-book/background/issuses/phaseouts.cfm (datum pristupa 25.10.2013.) 
Jaime Acosta M., 2011., Tax - Benefit Incidence of Value Added Tax Oн Food And Medicine To Fund Progressive Social Expenditure, ECINEQ Working Paper Series

Jovanović A. (2008) „Fiskalna harmonizacija u EU“. Ekonomika. Niš: Sven.

Ministarstvo finansija (2014) Bilten javnih finansija Republike Srbije, septembar, Dostupno na: http://www.mfin.gov.rs/UserFiles/File/bilten\%20javne\%20finansije/ bilten-121-web(1).pdf

Murphy R. (2011) "Why VAT is regressive?" Fair Tax. London. Dostupno na: http://www.taxresearch.org.uk/Documents/VATRegressive.pdf

Revenue statistics OECD (2000-2011) dostupno na: http://www.oecd-ilibrary.org/taxation/ revenue-statistics-2011_rev_stats-2011-en-fr

Švaljek S. (2011) Učinak ukidanja nulte stope PDV - a na nejednakost $i$ siromaštvo. Zagreb: Ekonomski institut.

\section{ZADOVOLJENJE PRINCIPA PRAVIČNOSTI U OPOREZIVANJU POTROŠNJE}

Apstrakt: Porezi na potrošnju zauzimaju značajno mesto u poreskim sistemima savremenih država. Njihovom naplatom obezbedi se veliki iznos prihoda za državni budžet. Međutim, i pored njihove velike izdašnosti, oni imaju izraženu regresivnost, što predstavlja njihovu negativnu karakteristiku. Problem regresivnosti podrazumeva da poreski teret poreza na potrošnju teže podnose slojevi stanovništva sa nižim dohotkom, pošto plaćaju porez po istoj stopi, kao i oni koji ostvaruju visoke dohotke. Cilj rada je da ukaže na postojanje problema regresivnosti $u$ nedovoljno razvijenim i razvijenim zemljama i na mogućnosti ublažavanja ovog problema u cilju zadovoljenja principa pravičnosti u oporezivanju.

Ključne reči: porezi na potrošnju, PDV, regresivnost, koeficijent distributivnosti, siromaštvo 